\title{
MIECZYSŁAW POLAK \\ „Duszpasterskie nawrócenie” jako wyraz nowej ewangelizacji w warunkach rozwiniętego modernizmu
}

Do podjęcia rozważań nad określonym w tytule artykułu zagadnieniem skłania wiele przesłanek: od utworzenia przez papieża Benedykta XVI Papieskiej Rady ds. Krzewienia Nowej Ewangelizacji oraz zwołania XIII Zgromadzenia Ogólnego Synodu Biskupów nt. Nowa ewangelizacja dla przekazu wiary chrześcijańskiej poprzez powołanie w ramach Komisji ds. Duszpasterstwa Konferencji Episkopatu Polski Zespołu ds. Nowej Ewangelizacji do licznych w ostatnich latach, zarówno naukowych, jak i popularnych publikacji, poruszających to zagadnienie $^{1}$. Refleksja ta motywowana jest również działalnością już istniejących, a także powstających nowych ruchów i grup ewangelizacyjnych, rozwojem akcji ewangelizacyjnych czy tzw. „szkół nowej ewangelizacji”. Prócz tego synodalne Lineamenta właśnie w kontekście nowej ewangelizacji postulują „nawrócenie duszpasterskie" różnych kościelnych wspólnot ${ }^{2}$.

Mieczysław P O L A K, ks. dr, adiunkt w Zakładzie Teologii Pastoralnej Wydziału Teologicznego UAM w Poznaniu, Gniezno, e-mail: mpolak@amu.edu.pl

${ }^{1} \mathrm{Z}$ naukowych opracowań wymienimy przykładowo kilka publikacji książkowych: Nowa ewangelizacja. Odpowiedzi na wyzwania obecnego czasu. Red. K. Góźdź. Lublin 1993; A. Le w e k: Nowa ewangelizacja w duchu Soboru Watykańskiego II. T. 1-2. Katowice 1995; K. P a w lin a: Nowa ewangelizacja i jej realizacja w Polsce po 1989 roku. Warszawa 1995; J.

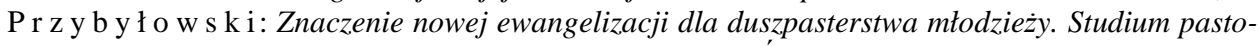
ralne. Lublin 2001; A. S e p i oło: Nowa ewangelizacja. Śladami Jana Pawła II. Kraków 2001; Ewangelizacja odpowiedziq Kościoła na wyzwania wspótczesności. Red. W. P r z y go d a, E. R o b e k. Sandomierz 2011; Nowa ewangelizacja wyzwaniem dla Kościoła w Polsce. Red. B. B i e 1 a. Katowice 2011.

${ }^{2}$ Synod Biskupów. XIII Zwyczajne Zgromadzenie Ogólne: NowA EWANGELIZACJA DLA PRZEKAZU WIARY CHRZEŚCIJAŃSKIEJ. Lineamenta. Watykan 2011 n. 10 [Tekst za: http://www.vatican. va/roman_curia/synod/documents/rc_synod_doc_20110202_lineamenta-xiii-assembly_pl.html - z dn. 5.11.2011]. 
Szerokie i wielowątkowe zagadnienie zostanie tutaj przedstawione w odniesieniu do głównych wyzwań płynących z kontekstu kulturowo-społecznego, w jakim Kościół pełni dziś swoje zbawcze posłannictwo. Kontekst ten zostanie określony jako „czas rozwiniętego modernizmu”. Uwarunkowania kulturowospołeczne i związane $\mathrm{z}$ nimi przemiany religijności stanowią jedną $\mathrm{z}$ istotnych przesłanek kształtujących duszpasterstwo Kościoła. Rozpoznanie zbawczej woli Bożej $w$ wymiarze ontologicznym czy kryteriologicznym, ale również $w$ wymiarze kairologicznym pozwala na adekwatne sformutowanie imperatywów pastoralnego działania ${ }^{3}$.

Ukazując ważniejsze przemiany rozwiniętego modernizmu nie chcemy tutaj analizować ich negatywnych przejawów, zagrożeń dla ewangelizacyjnej misji Kościoła czy rozwoju człowieka, zwłaszcza jego wiary. Postawimy całkiem odmienne pytanie, mianowicie o to, co dzisiejszy Kościół mógłby z tych przemian zaczerpnąć, czego nauczyć się od świata. W jednej ze swoich wypowiedzi podczas Soboru Watykańskiego II Karol Wojtyła stwierdził: Należałoby przemawiać w taki sposób, aby świat zobaczyt, że nie tylko pouczamy go w sposób autorytatywny, ale równocześnie poszukujemy z nim prawdziwych i sprawiedliwych rozwiazań trudnych problemów życia ludzkiego. Problem nie polega bowiem na tym, aby ukazać prawdę dobrze nam już znana, lecz idzie o to, w jaki sposób odnajdzie ja i przyswoi sobie świat. (...) Taka metoda nauczania odpowiada naszemu schematowi. (...) Wyklucza ona wszystko, co zdradza mentalność, że tak powiem »kościelna ${ }^{4}$.

\section{Indywidualizacja życia w czasach rozwiniętego modernizmu}

Podstawowym twierdzeniem, jakie w tym kontekście można przytoczyć jest przekonanie o bardzo istotnych zmianach kulturowo-społecznych, jakie dokonały się we współczesnych społeczeństwach odróżniając je w zasadniczy sposób od dotychczasowych. Jakkolwiek bowiem przemiany społeczne nie są nowym zjawiskiem, to jednak współczesne charakteryzowane są poprzez niespotykane dotąd tempo, rozmiar i różnorodność ${ }^{5}$. Dzisiejsze społeczeństwa ukazują się jako „mieszanina blasków i cieni” (FC 6), możliwości i przymusów, które stoją przed człowiekiem i przynoszą ze sobą zarówno niespotykane dotąd szanse rozwoju, jak i nowe zagrożenia. Pluralizm, wolność, możliwość i konieczność wyboru, komunikacja i informacja stanowią o kulturowo-ekonomicznym życiu społeczeństwa i nie mniej o codziennym, kształtują zarówno „wielką politykę”, jak i in-

${ }^{3}$ T. M a k o w s k i: Karla Rahnera »preferencyjna opcja pastoralna«. „Studia Gnesnensia”. R. 12: 1998 s. 84.

${ }^{4}$ Cyt. za - R. S k r z y p c z a k: Karol Wojtyta na Soborze Watykańskim II. Zbiór wystapień. Warszawa 2011 s. 286.

${ }^{5}$ II Sobór Watykański określił te przemiany jako „szybkie” i „,szerokie” - por. KDK 4. 
tymne międzyludzkie relacje. Społeczeństwa współczesne określane są najczęściej jako modernistyczne lub postmodernistyczne ${ }^{6}$. Coraz częściej jednak mówi się o różnych stopniach rozwoju modernistycznych społeczeństw np.: ograniczonego modernizmu, wczesnego modernizmu, połowicznego modernizmu, rozwiniętego modernizmu, czy postmodernizmu, zwanego niekiedy modernizmem postmodernistycznym.

Jeśli jednak przyjmuje się, że społeczeństwa modernistyczne zaczynają się rozwijać wskutek procesów industrializacji, jakie zaszły na końcu XVIII w., to obecne czasy wymagają z pewnością innego określenia. Chodzi tutaj nie tylko o sam rozwój, jaki dokonał się w tych społeczeństwach, lecz także, a może i przede wszystkim o wskazanie, że to, co w modernizmie przyjmowane było jako oczywiste (np. oświecenie, nauka, technika) od pewnego czasu stawiane jest pod znakiem zapytania. Coraz szersze kręgi społeczne stwierdzają, że modernistyczne przemiany i osiągnięcia nie są jednoznacznie pozytywne, ale przynoszą człowiekowi i społeczeństwu także wiele zagrożeń ${ }^{7}$. Aby jednak podkreślić ciągły rozwój modernistycznych społeczeństw, a jeszcze bardziej przeplatanie się w nim różnych dawnych i nowych elementów, mówi się o dzisiejszych czasach jako o czasach „,późnego”, „rozwiniętego”, „refleksyjnego” albo „,drugiego modernizmu” ". Te określenia, a zwłaszcza „drugi modernizm” czy „rozwinięty modernizm" wskazują na to, że podstawowe zasady modernizmu nie poszły w zapomnienie i nadal odgrywają w społeczeństwach swoją rolę, choć w sposób wyraźnie zmodyfikowany'.

Opisując społeczno-kulturowy kontekst „rozwiniętego modernizmu” wskazuje się na takie jego cechy charakterystyczne jak: pluralizm, wolność, globalizacja oraz indywidualizacja. W niniejszych rozważaniach ograniczymy się do tej ostatniej cechy, mianowicie do indywidualizacji życia. Uwarunkowane jest to tym, że owa indywidualizacja życia jest z jednej strony dominującą cechą czasów rozwiniętego modernizmu, a z drugiej - bardzo istotnie wpływającą na religijność.

Społeczny pluralizm i możliwości zrealizowania wolności stwarzają podstawy do indywidualizacji życia. Współczesny człowiek ceni wysoko swoją indy-

${ }^{6}$ Por. S. K n o b l o c h: Praktische Theologie. Ein Lehrbuch für Studium und Pastoral. Freiburg-Basel-Wien 1996 s. 164.

${ }^{7}$ K. D i e p o ld: Identität und Mystagogie. Hamburg 2006 s. 15.

${ }^{8}$ Por. R. B u c h e r: Die Theologie in postmodernen Zeiten. „Theologie und Glaube“. Jg. 79: 1981 s. $178-191$.

${ }^{9}$ Por. U. B e c k: Das Zeitalter der Nebenfolgen und die Politisierung der Moderne. W: Reflexive Modernisierung. Eine Kontroverse. Red. U. B e c k, A. Gi d d e n s, S. L a s h. Frankfurt a.M. 1996 s. 24. R. W e 1 s c h mówi w tym kontekście o ,postmodernistycznym modernizmie“, o czasach, które są równocześnie modernistyczne, jak i postmodernistyczne - por. W. W e ls c h. Unsere postmoderne Moderne. Berlin 1987 s. 24-34. 
widualność i niepowtarzalność ${ }^{10}$. Indywidualizacja, będąca zjawiskiem społecznym nie może być pochopnie oceniana w kategoriach moralnych jako indywidualizm czy egoizm. Indywidualizacja oznacza pewien proces, jaki dokonał się na obecnym etapie rozwoju nowoczesnych społeczeństw. Kompleksowe zmiany takie jak funkcjonalna dyferencja, strukturalna i ekonomiczna racjonalizacja, technologiczno-przemysłowe przyspieszenie obejmować zaczęły także te sektory życia społecznego, które do tej pory nie były tak silnie pod ich wpływem ${ }^{11}$.

Według K. Diepolda indywidualizacja posiada dwie zasadnicze, różnorodne perspektywy ${ }^{12}$. W swojej ogólnej, szerokiej perspektywie oznacza ona dążenie jednostki do większej niezależności od różnych instytucji społecznych. Tak rozumiana indywidualizacja nie jest zjawiskiem, które pojawiło się dopiero we współczesnych społeczeństwach. Jednym z bardziej znaczących motywów rozwoju społeczeństw od przed- do modernistycznych były procesy indywidualizacji, których celem było uwolnienie jednostki od różnorodnych społecznych zobowiązań i zależności, zwłaszcza w odniesieniu do różnych instytucji. Ta szeroka interpretacja indywidualizacji życia powinna zostać uzupełniona o jej ,,szczegółowe rozumienie". To z kolei obejmuje trzy podstawowe aspekty, określające zasadnicze wymiary indywidualizmu czasów rozwiniętego modernizmu.

Pierwszy z nich to „wymiar wyzwolenia”. Z jednej strony prowadzi on do uwolnienia człowieka od historycznie uwarunkowanych różnych form społecznych, z drugiej pozbawia go społecznego i osobistego wsparcia, jakie wiązało się z tymi formami. Drugi wymiar to „odczarowanie”. Oznacza on utratę tradycyjnych pewników w odniesieniu do wiary, norm postępowania, światopoglądu. Procesy sekularyzacyjne zamazały dość jasny we wcześniejszych społeczeństwach obraz świata i życia ludzkiego, pozwalający dostrzec wyraźnie określony ich sens. W to miejsce pojawiło się wiele interpretacji, często przeciwnych, które wymagają od jednostki wyboru, własnych poszukiwań określonego sensu. Trzeci wymiar to wymiar ,reintegracji”. Polega ona na ponownej jakby integracji społecznej, utraconej wskutek osłabienia więzów rodzinnych i klasowych. Integracja ta dokonuje się poprzez sieć różnych uwarunkowań i zaleceń instytucjonalnych, które próbują przywrócić jednostce utraconą orientację ${ }^{13}$.

Dla $\mathrm{H}$. Wahla indywidualizacja jako społeczno-strukturalny proces oznacza najpierw utratę znaczenia tradycyjnych więzi społecznych. Współczesne procesy indywidualizacji dotyczą dalej nie tylko wybranych, elitarnych grup społecznych,

${ }^{10}$ Por. P. M. Zu le h n e r: Vom Untertan zum Freiheitskünstler. Eine Kulturdiagnose anhand der Untersuchungen »Religion im Leben der Österreicher 1970 bis 1990«. Europäische Wertestudie - Österreichteil 1990. Wien 1990 s. 17.

${ }^{11}$ Por. N. M e t $\mathrm{t}$ e: Trends in der Gegenwartsgesellschaft. W: Handbuch Praktische Theologie. Red. H. H a s 1 i n ge r. Bd. 1. Grundlegungen. Mainz 1999 s. 86-87.

${ }^{12}$ Por. K. D i e p o 1 d: Identität und Mystagogie, dz. cyt., s. 19-28.

${ }^{13}$ Tamże. 
ale przybierają charakter masowy, a jednostka oraz społeczne opcje na rzecz jej praw i znaczenia wzrastają. Następnie procesy te prowadzą do pluralizmu form życia, powiązanego z utratą poczucia życiowej stabilizacji. Wreszcie dotyczą one także obszaru życia religijnego, prowadząc do indywidualizacji religijności ${ }^{14}$.

Opisując proces indywidualizacji we współczesnych społeczeństwach S. Knobloch rozróżnia pomiędzy indywidualizacją będącą społeczno-historyczną kategorią oraz stanowiącą subiektywne doświadczenie człowieka ${ }^{15}$. Indywidualizacja jako społeczna kategoria związana jest $\mathrm{z}$ następującymi obiektywnymi momentami: uwolnieniem jednostki z wielu dotychczasowych powiązań, utratą poczucia życiowej stabilności oraz pojawieniem się nowych instytucjonalnych struktur kontroli jednostki. Silne do tej pory związki jednostki z życiem rodzinnym, z określoną grupą czy klasą społeczną, ze stabilną pracą ulegają dużemu rozluźnieniu. Socjologowie mówią o wyzwoleniu się jednostki z różnych wcześniejszych związków. Zaznaczają przy tym jednak często, że to wyzwolenie ma charakter ambiwalentny. $Z$ jednej strony jawi się jako otwarcie nowych możliwości, z drugiej przynosi niepewność życia, wymaga gotowości do wielu zmian $^{16}$.

Ostatnią z wymienionych przez Knoblocha cech społeczno-historycznej indywidualizacji jest powstanie nowych instytucjonalnych mechanizmów kontrolnych. Uwolniony z wielu związków i zależności współczesny człowiek w paradoksalny sposób poddany zostaje różnorodnej kontroli. Wspomniane wyżej uwarunkowania rynku pracy, zależność od wykształcenia, ofert konsumpcji, mody, społecznych reguł i zabezpieczeń wprowadzają, w miejsce starych, nowe powiązania i systemy kontroli. Funkcję kontrolną spełnia też egalizacja i standaryzacja życia przez media, zwłaszcza przez telewizję ${ }^{17}$.

Wracając do podziału zaproponowanego przez S. Knoblocha proces indywidualizacji rozpatrywany powinien być także jako subiektywne doświadczenie człowieka. Tutaj jednak napotyka się na wiele rozbieżności pomiędzy, jak się wydaje, obiektywnymi możliwościami jakie niosą ze sobą społeczne procesy indywidualizacji życia, a subiektywnym doświadczeniem człowieka. Najpierw będzie to rozdźwięk pomiędzy „mitem wolności a rzeczywistym doświadczeniem wolności”. Modernistyczna świadomość kształtowana była poprzez optymizm, który ukazywał człowiekowi nieograniczone wręcz możliwości działania, przekształcania świata i organizowania własnego życia. Świadomość postmodernistyczna skłania się ku przekonaniu, że optymizm ten poddany został zasadni-

${ }^{14}$ Por. H. W a h 1: LebensZeichen von Gott - für uns. Analysen und Impulse für eine zeitgemäße Sakramentenpastoral. Berlin 2008 s. 43.

${ }^{15}$ Por. S. K n o b l o c h: Praktische Theologie, dz. cyt., s. 167-174. 208-209.

${ }^{16}$ Por. U. B e c k: Risikogesellschaft. Auf dem Weg in eine andere Moderne. Frankfurt $1986 \mathrm{s.}$

${ }^{17}$ Por. S. K n o b 1 o c h: Praktische Theologie, dz. cyt., s. 169. 
czym korektom. Z jednej strony pojawiło się wiele nowych ograniczeń ludzkiego działania, z drugiej - podejmowane $\mathrm{z}$ takim optymizmem przedsięwzięcia, mające na celu poprawę jakości życia prowadzą do czegoś zupełnie odwrotnego. Stąd subiektywne doświadczenie indywidualizacji i wolności może znacząco odbiegać od społecznych ich założeń ${ }^{18}$.

K. Gabriel określa współczesne procesy indywidualizacji jako ambiwalentne i wymienia ich cztery wymiary. Pierwszy z nich określa jako ,wyzwolenie z tradycyjnych społecznych więzi”, takich jak np.: związki rodzinne, środowisko pochodzenia i związane z nim możliwości kształtowania własnego życia, związki z lokalnymi, małymi grupami, jak i z dużymi środowiskami. Ów proces wyzwolenia jest znów ambiwalentny. Niesie ze sobą zarówno szanse rozwoju, jak i powoduje utratę poczucia przynależności do określonego środowiska, czy grupy, co nie jest też dla jednostki bez znaczenia. Drugi wymiar indywidualizacji charakteryzuje się procesami „odczarowania” dotychczasowego, związanego z przekazem tradycji, w miarę jednorodnego światopoglądu. Pozwala to człowiekowi na bardziej samodzielne ukształtowanie osobistego poglądu na świat, a przez to też większą identyfikację $\mathrm{z}$ określoną jego wizją, ale pozbawia go równocześnie pewnych ogólnych ram orientacyjnych, które są niezmiernie pomocne, niekiedy niezbędne przy wypracowaniu osobistych poglądów.

Trzeci wymiar procesów indywidualizacji wiąże się z pojawieniem się $\mathrm{w}$ nowoczesnych społeczeństwach nowych zniewoleń, ograniczeń, przymusów. W paradoksalny sposób społeczeństwa wolnościowe przynoszą ze sobą wiele sytuacji, które zmuszają jednostkę do podejmowania określonych decyzji. Indywidualizacja nie likwiduje społeczeństwa i jego reguł życia. Zyskują one tylko inny punkt odniesienia, jakim jest teraz „samo indiwiduum i etapy jego historii życia”. Czwarty wreszcie wymiar procesu indywidualizacji związany jest z możliwościami kształtowania własnej biografii. Wiąże się to $\mathrm{z}$ podejmowaniem wielu decyzji, z których każda jest w zasadzie ambiwalentna i wprowadza napięcie pomiędzy różnymi obszarami życia: świat pracy, kariera, małżeństwo, wychowanie dzieci itp. ${ }^{19}$.

Współczesne modernistyczne społeczeństwo jest pierwszą w historii ludzkości taką kulturową formacją, która jednostkę skazuje na to, iż musi ona poradzić sobie bez określonych, trwałych wartości i odniesień. W ten sposób musi się zdecydować na takie życie, które jest w zasadzie „otwartym eksperymentem”. W tym kontekście ukazują się bardzo dobrze podstawowe doświadczenia współczesnego indywidualizmu. Zawierają one w sobie zarówno elementy wolności i

\footnotetext{
${ }^{18}$ Por. tamże, s. $170-171$.

${ }^{19}$ Por. E. G a b r i e 1: Gesellschaftliche Veränderungen als Zeichen der Zeit. W: W. K r i e g e r, A. S c hwarz: Kirche in der Welt von heute - Ein kritisches Verhältnis. Österreichische Pastoraltagung 28. bis 30 Dezember 1995. Würzburg 1996 s. 14-16.
} 
związanych z nią możliwości, jak i elementy osamotnienia, pozostawienia przez społeczeństwo bez jakiegokolwiek wsparcia. Doświadczenie to nie jest łatwe i powodować może tłumienie głębszych potrzeb poprzez ucieczkę w świat konsumpcji. Jednak przy rosnącej dziś sferze ubóstwa powiększa się także liczba tych, którzy żyją jakby na obrzeżach społeczeństwa, w „zmarginalizowanych grupach" ${ }^{\text {20 }}$.

Subiektywnie doświadczany indywidualizm połączony z niepewnością życia, z brakiem struktur, które zapewniałyby względną stabilizację skłania jednak niektórych do podejmowania kroków, zmierzających do wchodzenia $\mathrm{w}$ silne społeczne związki, związane najczęściej z różnego rodzaju ruchami fundamentalistycznymi, czy to na płaszczyźnie narodowej czy religijnej. Ruchy te mają jasno określone struktury oraz sprecyzowane i jednoznaczne poglądy na rzeczywistość. Pluralizm społeczny i religijny oraz indywidualizm oceniają negatywnie. Starają się budować dla swoich zwolenników taką przestrzeń życia, w której będą oni czuli się bezpiecznie i będą przekonani o słuszności swoich przekonań $\mathrm{w}$ przeciwieństwie do błędnych teorii panujących w świecie. Zwolennicy tych ruchów pochodzą często spośród tych grup, które dotknięte są współczesnymi problemami społecznymi. Nazywani bywają niekiedy „ofiarami modernizmu”21.

Modernistyczne procesy indywidualizacji są zatem bardzo różnorodne i wielopłaszczyznowe. Zawierają $\mathrm{w}$ sobie wiele ambiwalentnych zjawisk i problemów, niosących współczesnemu człowiekowi dokładnie tyle samo szans, co i zagrożeń $^{22}$. Indywidualizacja, która oceniana jest jako pozytywna wartość, napotyka w nowoczesnych społeczeństwach w paradoksalny sposób na wiele granic i trudności w jej realizacji przez jednostkę. Negatywne zjawiska z nią związane wydają się być wspierane przez różne społeczne faktory modernizmu. Stąd we współczesnych społeczeństwach rozwinęły się różnego rodzaju profesjonalne poradnictwa i doradztwa, które mają pomóc jednostce odnaleźć się w skomplikowanym świecie modernistycznych społeczeństw.

\section{Indywidualizacja religijności w warunkach rozwiniętego modernizmu}

P. M. Zulehner prowadził przez wiele lat badania religijności Austriaków. Badania długoterminowe posiadają w odniesieniu do jednorazowych wiele zalet, między innymi tę, że pokazują pewne kierunki rozwoju czy trendy i pozwalają

${ }^{20}$ Por. S. K n o b lo c h: Mystagogie und Subjektwerdung. „Theologisch-Praktische Quartalschrift". Jg. 141: $1993 \mathrm{nr} 2$ s. 148-150.

${ }^{21}$ W. H e i t m e y e r: Das Desintegrations-Theorem. Ein Erklärungsansatz zu fremdfeindlich motivierter, rechtextremistischer Gewalt und Lähmung gesellschaftlicher Institutionen. W: Das Gewalt-Dilemma. Frankfurt a.M 1994 s. 67.

${ }^{22}$ Por. S. K n o b 1 o c h: Mystagogie und Subjektwerdung, dz. cyt., s. 149-150. 
lepiej prognozować przemiany, jakie będą miały miejsce w przyszłości. W wydanych niedawno studiach obejmujących lata 1970-2010 austriacki pastoralista określa przemiany, jakie zaszły w tym czasie w obszarze życia religijnego jako „epokową transformację"23.

Teza o indywidualizacji religijności próbuje w pewien sposób skorygować paradygmat sekularyzacji i obraz zsekularyzowanego społeczeństwa. Indywidualizacja religii i religijności związana jest strukturalnie z ogólnymi, uwarunkowanymi społecznie procesami indywidualizacji, które zostały przedstawione powyżej w zarysie. Byłoby raczej niemożliwym, albo co najmniej bardzo trudnym, aby także obszar życia religijnego nie został poddany indywidualizacji, skoro wszystkie inne są pod jej wpływem. Chodzi tutaj zarówno o samo rozumienie znaczenia religii $\mathrm{w}$ życiu człowieka, o jej treści, jak i o praktyki religijne. W tej sytuacji religii przypada zadanie, aby we właściwy jej sposób przepracowała ów obszar odnajdywania indywidualności jednostki, który przez społeczeństwo już prawie w ogóle nie jest wspomagany ${ }^{24}$.

S. Knobloch, powołując się na K. Gabriela ${ }^{25}$ przestawia trzy podstawowe wymiary sekularyzacji. Pierwszy z nich określa sekularyzację jako „funkcjonalną i strukturalną dyferencję społeczeństwa”. W zasadzie sekularyzacja stanowi jeden $\mathrm{z}$ aspektów owej dyferencji, który obejmuje różnorodne obszary życia społecznego. Drugi wymiar sekularyzacji to „zmniejszenie się i osłabienie wiary religijnej i religijnych praktyk". Można powiedzieć, że ten wymiar jest dziś szczególnie mocno zauważalny, zwłaszcza w krajach zachodnioeuropejskich. Jednak analiza tego wymiaru sekularyzacji jest mocno uzależniona od przyjętych w niej kryteriów wiary i praktyk religijnych. Trzeci wreszcie wymiar określany jest jako „wycofywanie się religii do sfery życia prywatnego”. Stąd indywidualizacja i prywatyzacja religijności związane są nie tylko z ogólnymi tendencjami indywidualistycznymi, lecz także z procesami sekularyzacji ${ }^{26}$.

Nowoczesne społeczeństwa charakteryzują się zdecydowanym osłabieniem tradycji, w sensie przekazywania z pokolenia na pokolenie systemów wartości, norm moralnych, sposobu życia itp. Nowe pokolenia przejmują coraz mniej od poprzednich, tworzą nowe rzeczywistości. Przyczyny tego zjawiska są z pewno-

\footnotetext{
${ }^{23}$ Por. P. M. Z u 1 e h n e r: Verbuntung. Kirchen im weltanschaulichen Pluralismus. Religion im Leben der Menschen 1970-2010. Ostfildern 2011 s. 25.

${ }^{24}$ Por. S. K n o b 1 o c h: Mehr Religion als gedacht. Wie die Rede von Säkularisierung in die Irre führt. Freiburg-Basel-Wien 2006 s. 83.

${ }^{25}$ Por. K. Gabrie 1: Zwischen Säkularisierung, Individualisierung und Entprivatisierung. Zur Widersprüchlichkeit der religiösen Lage heute. W: W. K n u t: Erosion. Zur Veränderung des religiösen Bewusstseins. Luzern 2000 s. 9-28; T e n ż e: Säkularisierung und öffentliche Religion. Religionssoziologische Anmerkungen mit Blick auf den europäischen Kontext. W: Jahrbuch für christliche Sozialwissenschaften. Religionen im öffentlichen Raum; Perspektiven in Europa. Münster 2003 s. 13-36.

${ }^{26}$ Por. S. K n o b l o c h: Mehr Religion als gedacht, dz. cyt., s. 84-88.
} 
ścią wielorakie. Jedną z nich jest tempo rozwoju społeczno-kulturowego, technicznego czy gospodarczego. Pokolenie młodych dorosłych żyje w znacznie odmiennych uwarunkowaniach od pokolenia ich rodziców. Uwarunkowania te wpływają bardziej niż tradycja na ich sposób myślenia i działania. Dotyczy to również tradycji religijnej. Dlatego mówi się o współczesnej „niestabilności” religijności, tzn. że przekaz doświadczenia religijnego, wiedzy religijnej czyli tradycja i socjalizacja religijna stają się coraz słabsze. Zjawisko to jest w dużej mierze skutkiem coraz słabszych „kompetencji religijnych” kolejnych pokoleń ${ }^{27}$. Niewątpliwie są one owocem opisanych wcześniej procesów sekularyzacyjnych. W zjawisku tym należałoby szukać jednego z ważniejszych powodów indywidualizacji religii. Skoro słabną procesy społecznej i rodzinnej socjalizacji religijnej jednostka „skazana” jest niejako na konstruowanie własnego modelu religijności.

Indywidualizacja religijności czy jej prywatyzacja są z jednej strony zjawiskami pozytywnymi. Dzieje się tak wtedy, kiedy pod tymi pojęciami rozumiana jest jednocześnie personalizacja religijności. Ponieważ religijność jest głęboko osobową zdolnością człowieka i rzeczywistością intymną, wymaga ona szczególnej ochrony, aby być wolną i taką móc pozostać. Twierdzenie to można także uzasadnić teologicznie, gdyż tę osobową relację pomiędzy Bogiem i człowiekiem oraz jej jakość może ostatecznie ocenić tylko Bóg. Takie jednak rozumienie procesów indywidualizacji religijności nie oznacza, że staje się ona sprawą prywatną. Będąc rzeczywistością o głębokim wymiarze indywidualnym i osobowym zawiera w sobie także wymiar wspólnotowy. Obraz Boga, który posiada jednostka oraz realizacja przez nią religijności ukształtowane są przez tworzoną przez innych historię wiary i uwarunkowania kulturowe. Jaki kto poznaje obraz Boga, jak myśli o religii, jak wyraża swoją religijność, jakim mówi o niej językiem, jakich używa symboli - wszystko to związane jest głęboko z innymi ludźmi, z ich światem religijnym. Stąd religii i religijności nie da się zredukować tylko do sfery prywatnej. Religia posiada bowiem wymiar zarówno osobowy, jak i polityczny ${ }^{28}$.

$\mathrm{Z}$ drugiej jednak strony owa indywidualizacja i prywatyzacja religii i religijności stanowi pewne zagrożenie dla właściwego ich rozwoju. Dla wielu bowiem współczesnych termin ,prywatny” nie pokrywa się z pojęciem „osobowy”, a tym bardziej nie zawiera $\mathrm{w}$ sobie wspomnianego powyżej wymiaru społecznokulturowego. W ten sposób owa indywidualizacja i prywatność oznaczają o wiele bardziej zjawiska uzależniające zarówno poglądy, jak i praktyki religijne tylko od jednostki, od jej osobistych, prywatnych zapatrywań. Wybieram z religii to, co jest dobre dla mnie, co odpowiada mojej koncepcji religii, co jest dla mnie

\footnotetext{
${ }^{27}$ Por. R. P o l a k: Religion kehrt wieder. Handlungsoptionen in Kirche und Gesellschaft. Ostfildern 2006 s. 82-83.

${ }^{28}$ Por. tamże, s. $83-84$.
} 
przydatne, dla realizacji mojej koncepcji szczęścia. Religia i religijność zyskują wtedy tylko wartość, kiedy służą zaspokojeniu osobistych dążeń jednostki ${ }^{29}$.

Procesy indywidualizacji i prywatyzacji religii wpływają znacząco na ukształtowanie się jednego $\mathrm{z}$ ważniejszych faktorów religijności, mianowicie dominującej relacji pomiędzy obywatelami a religią i Kościołem ${ }^{30}$. Relacja ta określana jest dziś nie tyle przez oczekiwania Kościoła wobec obywateli, co poprzez to, czego obywatele od Kościoła oczekują. „Reżyseria” relacji do Kościoła leży teraz po stronie obywateli, którym pluralistyczne społeczeństwo stwarza także w tej dziedzinie duże możliwości. Procesy samostanowienia, które początkowo dotyczyły prywatnego obszaru życia zostały również rozciągnięte na obszar religijności, a przez to na relacje do Kościoła. Indywidualizacja i prywatyzacja religii powodują także rozróżnienia w obrębie jednego wyznania, czy Kościoła. Dotyczą one np. braku konsensusu w uznaniu oficjalnego nauczania danego Kościoła. Jak nigdy dotąd można dziś zauważyć krytyczne nastawienie do oficjalnej Nauki Kościoła i to nie tylko w akademickiej teologii, ale i u wielu chrześcijan, nie wyłączając biskupów i kapłanów ${ }^{31}$.

Kolejnym zjawiskiem łączącym się z indywidualizacją religii jest ograniczenie religijności do ciasnego obszaru rodzinnego, do kręgu krewnych i znajomych oraz do takich wydarzeń życiowych jak narodziny, małżeństwo, jubileusze, śmierć. Wydarzenie te wiążą się często $\mathrm{z}$ ambiwalentnymi przeżyciami i doznaniami, zawierającymi w sobie pewien element niepewności, troski o przyszłość, potrzeby odwołania się do Boga, jako gwaranta szczęścia czy błogosławieństwa, a także z wymiarem świętowania. Dlatego potrzebują z reguły pewnych rytów, aby mogły być wyrażone czy symbolicznie wypowiedziane. Traktowane są one jednak bardziej jako wydarzenia rodzinne, dotyczące najbliższych, a nie wspólnoty Kościoła ${ }^{32}$.

Analiza dominującej we współczesnych społeczeństwach relacji do Kościoła wskazuje na kilka zasadniczych jej cech. Najpierw należy stwierdzić, że pojęcia „kościelność” i „religijność” nie oznaczają tego samego. W czasach rozwiniętego modernizmu rozwinęła się nie tylko „pozakościelna religijność”, ale także religijność nie mająca mocniejszego związku z żadną religią, grupą czy wspólnotą wyznaniową. Religijność ta w odniesieniu do treści jest często dość mglista $\mathrm{i}$ niejednoznaczna. W formach wyrazu odwołuje się do praktyk z różnych religii,

${ }^{29}$ Por. U. E i b a c h: Liebe, Glück und Partnerschaft. Sexualität und Familie im Wertewandel. Wuppertal 1996 s. 64-65.

${ }^{30}$ Por. P. M. Z u l e h n e r: Pastoraltheologie. Bd. 1. Fundamentalpastoral. Düsseldorf 1991 s. $202-211$

${ }^{31}$ Por. E. S a n d ri e s s e r: Theologie und Praxis. 24 Thesen. W: Kirche in der Gesellschaft. Wege in das 3. Jahrtausend. Red. Sekretariat der Österreichischen Bischofskonferenz. Wien 1997 s. 47.

${ }^{32}$ Por. P. M. Z u 1 e h n e r: Pastoraltheologie. Bd. 1, dz. cyt., s. 207. 
tradycyjnych i nowych, będących też wyrazem indywidualnie ukształtowanej

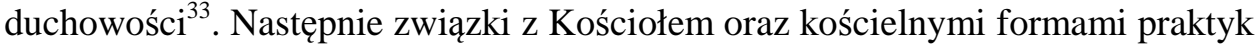
religijnych pojawiają się $\mathrm{w}$ określonych momentach życia. Tam, gdzie tradycja religijna jest jeszcze żywa, zdecydowana większość opowiada się za potrzebą kościelnych rytów, związanych z narodzinami dziecka, dojrzewaniem (bierzmowanie), z zawarciem małżeństwa oraz ze śmiercią ${ }^{34}$. Wreszcie religijność, a szczególnie kościelność współczesnych zależy coraz mniej od pochodzenia czy tradycji religijnej, w której ktoś się urodził, ale od osobowych kontaktów z tymi, którzy do danej wspólnoty religijnej czy kościelnej przynależą lub ją reprezentują, co powoduje dyferencję pomiędzy instytucjonalną $\mathrm{i}$ indywidualną religijnością, będącą w dużej mierze skutkiem funkcjonalnej dyferencji społeczeństwa ${ }^{35}$.

\section{Niektóre aspekty „,duszpasterskiego nawrócenia” w kontekście rozwiniętego modernizmu}

Główne wyzwanie duszpasterskie w kontekście nakreślonych powyżej przemian synodalne Lineamenta formułują w następujący sposób: W tym właśnie tkwi specyfika i moc tego narzędzia, jakim jest nowa ewangelizacja: trzeba patrzeć na te konteksty, na te zjawiska, umiejac przezwyciężyć warstwe emotywna oceny obronnej i zalęknionej, aby w sposób obiektywny dostrzec przejawy, wyzwania i kruchość tego, co nowe. "Nowa ewangelizacja« oznacza zatem starać się $w$ naszych Kościołach lokalnych wypracowywać sposoby odczytywania wspomnianych powyżej zjawisk $w$ taki sposób, by nadzieję Ewangelii przetożyć na stowa, które można wprowadzić w życie (Lineamenta 7).

Analizowanie kontekstów i zjawisk społeczno-kulturowych, w jakich dokonuje się życie Kościoła jest zagadnieniem wciąż aktualnym. Zmiany dokonujace się $w$ przestrzeni kulturowej $w$ wyniku różnorakich nurtów myślowych winny być stale obserwowane $i$ teologicznie interpretowane, aby można byto wypracowywać do aktualnych modeli teologicznych odpowiadajace im imperatywy i programy działania, na podstawie których powinna być prowadzona działalność ewangelizacyjna $w$ konkretnych wspólnotach eklezjalnych ${ }^{36}$. Do tej analizy należy także poszukiwanie odpowiedzi na pytanie nie tylko o współczesne zagrożenia dla procesu ewangelizacji, ale również o nowe możliwości i szanse. Chodzi

\footnotetext{
${ }^{33}$ Por. K. R e me l e: Die Reise ins Innere: Spiritualität als Heilung. W: Spiritualität - mehr als ein Megatrend. Red. P. M. Z u 1 e h n e r. Ostfildern 2004 s. 47-49.

${ }^{34}$ Por. I. R a g u z: Sakramente als Übergänge. Rituale (rite de passage) im Leben des Menschen. „Pastoraltheologische Hefte“. Jg. 3: 2010 s. 14-23.

${ }^{35}$ H-G. Z i e b e r t z: Religion, Christentum und Moderne. Veränderte Religionspräsenz als Herausforderung. Stuttgart-Berlin-Köln 1999 s. 61-62.

${ }^{36}$ B. D ro żd ż: Uwarunkowania spoteczno-kulturowe ewangelizacji w Polsce na poczatku XXI wieku. W: Ewangelizacja odpowiedzia Kościoła w Polsce na wyzwania wspótczesności. Red. W. Pr z y g o d a, E. R o b e k. Sandomierz 2011 s. 57.
} 
tutaj także o uczenie się Kościoła od świata, co jak wskazano na początku przedłożenia stanowi charakterystyczny rys niniejszych rozważań.

Jedną z cech współczesnych przemian kulturowo-społecznych jest szeroko pojęta specjalizacja i profesjonalizacja. Można je zauważyć w wielu dziedzinach życia, zwłaszcza w nauce, polityce, przemyśle, edukacji czy mediach. Działający w takim kontekście Kościół, „duszpastersko się nawracający” powinien rozważyć nowe wyzwanie, które może być określone jako „profesjonalizacja działań pastoralnych”. Zarówno poznanie „oblicza nowych okoliczności”, jak i „odwaga próbowania nowych dróg" wymagają dziś pogłębionej i fachowej refleksji teologicznej. Jednym z wyznawanych dziś przez Kościół w Europie Zachodniej błędów przeszłości jest zbyt małe uwzględnienie w działalności duszpasterskiej, zwłaszcza na etapie tworzenia koncepcji duszpasterskich i programowania duszpasterskiego, potencjału intelektualnego i duchowego wydziałów teologicznych. Należałoby sobie życzyć - stwierdza P. M. Zulehner - aby Kościót w Polsce uczyt się na btędach wspólnot Zachodu ${ }^{37}$.

Nie zawsze jednak i w Kościele w Polsce udaje się uniknąć tych błędów. Zaproszona przez Komisję Duszpasterstwa Konferencji Episkopatu Polski [KEP] do współpracy nad koncepcją programu duszpasterskiego dla Kościoła w Polsce grupa pastoralistów ze wszystkich znaczących ośrodków naukowych opracowała zarys dwudziestoletniego projektu opartego na pogłębionej refleksji teologicznej, obejmującej zarówno nauczanie Kościelne, refleksję teologiczną, jak i wnikliwą analizę znaków czasu ${ }^{38}$. W „Słowie wstępnym” do Programu duszpasterskiego 2010-2013 przewodniczący Komisji Duszpasterstwa KEP, abp Stanisław Gądecki, tak opisał tę współpracę: Za Pośrednictwem Prezesa Polskiego Stowarzyszenia Pastoralistów i Duszpasterzy im. Jana Pawła II ks. prof. dra hab. Jana Przybytowskiego, do wspótpracy zostato zaproszone środowisko polskich pastoralistów. Wspólna prace rozpoczęło sympozjum w Sieradzu 28 października 2008 r. W toku dalszej wspótpracy, kilku pastoralistów przybyto do Poznania na spotkanie poświęcone temu zagadnieniu (25 września 2009 r.). Grupa ta - pracujaca pod kierunkiem Przewodniczqcego Komisji Duszpasterstwa - przygotowała zarys projektu Programu Duszpasterskiego dla Kościoła katolickiego w Polsce na okres 20 lat $^{39}$.

\footnotetext{
${ }^{37}$ Trzeba ruszyć głowa. Wywiad z ks. prof. Paulem M. Zu le h n e re m. „Tygodnik Powszechny". R. 2011 nr 39 (3246) s. 5.

${ }^{38}$ Jeśli chodzi o długofalowe spojrzenie, to także tutaj należałoby uczyć się od współczesnego świata. Raport przygotowany przez Zespół Doradców Strategicznych Prezesa Rady Ministrów ukazuje drogi rozwoju w perspektywie dwudziestoletniej. Zob. Polska 2030. Wyzwania rozwojowe. Red. M. B o n i. Warszawa 2009.

${ }^{39}$ Komisja Duszpasterstwa KEP: W komunii z Bogiem. Kościót domem i szkoła komunii. Program duszpasterski Kościoła w Polsce na lata 2010-2013. Red. S. S t u 1 k o w s k i. Poznań 2010 s. 9.
} 
Projekt ten jednak nie został przez Konferencję Episkopatu, obradującą w dniach 6-7 października 2009 r. przyjęty, ani nawet poddany głębszej refleksji i merytorycznej dyskusji. Głównym argumentem jego odrzucenia była zbyt dalekosiężna wizja, obejmująca 20 lat. Spojrzenie jednak na współczesne sposoby planowania i programowania, jakie wypracowane zostały w ,świecie”, postulowałoby właśnie potrzebę długofalowego programu duszpasterskiego, bo tylko ów długofalowy program pozwoliłby na realizację określonej wizji Kościoła. Nie wyklucza on też podziału tej wieloletniej koncepcji na pewne etapy realizacji, niemniej tworzące określona całość, zawartą w wizji wieloletniego programu. Redaktor wspomnianego programu stwierdził w jednej ze swoich wypowiedzi: Szkoda, że pasterze Kościoła katolickiego w Polsce nie odważyli się pójść za prorocza wizja wskazana przez Jana Pawła II, by zagadnieniu czynienia Kościota domem i szkoła komunii poświęcić przynajmniej druga i trzecia dekadę nowego tysiaclecia. Już sam fakt sformułowania tematu inaczej niż proponowat to papież wskazuje na brak gotowości przyznania się do faktu, że Kościót wciąz na nowo musi się uczyć, jak stawać się komunią ${ }^{40}$.

Efekt owego braku ,profesjonalizacji działań pastoralnych” bardzo trafnie przedstawił także A. Przybecki, którego to refleksja została zamieszczona w samym Programie duszpasterskim 2010-2013 - „Kościół domem i szkołą komunii”, wydanym przez wspomnianą powyżej Komisję: W tym kontekście należy stwierdzić, że zredukowanie do trzech lat pierwotnego projektu programu duszpasterskiego (...) jest świadectwem niezrozumienia wagi i znaczenia problematy$k i$, zawartej $w$ haśle programu. Nie jest ona bowiem nośnym jedynie i medialnie atrakcyjnym sloganem, ale dotyka samej istoty tego, co winniśmy traktować jako odpowiedź na stawiane po przełomie roku 1989 ciagle pytanie: Jak być Kościotem $w$ Polsce dzisiaj. Tymczasem odnieść można wrażenie, że po dwudziestu latach od upadku komunizmu w naszym myśleniu pokutuje jeszcze duch realnego socjalizmu, w którym zamiast prawdziwej czekolady, serwowano produkty czekoladopodobne. Podobnie w odniesieniu do planowania duszpasterskiego - zamiast programu z prawdziwego zdarzenia, otrzymujemy produkt programopodobny ${ }^{41}$.

Zanim zatem - podobnie jak w Europie Zachodniej - zamykać będziemy wydziały teologiczne, może warto odważyć się na zainwestowanie w te jednostki naukowe, zwłaszcza „ludzkiego kapitału”, aby w ten sposób przeciwstawić się samowystarczalności i poleganiu na sobie samym, mentalności status quo i takiemu pojmowaniu duszpasterstwa, które sadzi, że wystarczy dalej postępować tak, jak się postępowato zawsze. Dziś »business as usual« już nie wystarcza (Lineamenta 10). Tutaj także warto skorzystać z doświadczeń świata, który rozwinął

\footnotetext{
${ }^{40}$ S. S tu łkowski: Kapłan sługa komunii. Od osobistej więzi do posłannictwa jedności. „Teologia Praktyczna”. T. 11: 2010 s. 78.

${ }^{41}$ A. P r z y b e c k i. »Czynić Kościót domem i szkoła komunii«. Zadania dla Kościoła w Polsce. W: Komisja Duszpasterstwa KEP: W komunii z Bogiem, dz. cyt., s. 214.
} 
wiele programów dotyczących tzw. „kapitału ludzkiego”,42. W Kościele „kapitał ludzki” ma o wiele większe znaczenie niż w świecie, bo „człowiek jest drogą Kościoła”. Zatem brak inwestycji w ów „kapitał ludzki” czy wręcz niszczenie go poprzez błędną politykę personalną - zwłaszcza w diecezjach, tam gdzie większość owych decyzji zapada, wymagają zdecydowanego „nawrócenia duszpasterskiego".

Drugie postulat, jaki jawi się „w obliczu nowych okoliczności” ewangelizacyjnych to odejście od wyłącznie socjologicznego postrzegania Kościoła i jego duszpasterskiej działalności. Jakkolwiek nie można lekceważyć kryterium ilościowego, to jednak trzeba mieć w pamięci owo doświadczenie historyczne Kościoła, które mówi iż nie był on nigdy silny ilością. Wypełnione w okresie „Solidarności” kościoły, w jakiejś mierze, uśpiły raczej duszpasterską wrażliwość i podniosły stopień samozadowolenia, niż skłoniły do podjęcia pogłębionej formacji chrześcijańskiej. Dziś nie do końca została owa „mentalność socjologiczna” przezwyciężona i nadal duszpasterskie działania oceniane są poprzez kryterium ilościowe. Sytuację tę dobrze opisuje Teolog Domu Papieskiego o. Wojciech Giertych OP: Można podliczyć ludzi wg »dominicantes czy communicantes«. Można też zadawać im pytania $w$ rodzaju: Czy wierzysz $w$ istnienie diabła? Czy dzielisz się opłatkiem na święta? Czy akceptujesz naukę Kościoła w sprawie antykoncepcji? Konkluzje takiego socjologicznego studium daja pewien obraz spoteczeństwa, jego praktyk religijnych oraz etosu. Moga one coś niecoś powiedzieć o miejscu Kościoła jako rzeczywistości widzialnej w życiu konkretnej społeczności. Jest to jednak opis zewnętrzny, niewnikający w istote misterium Kościota: dla polityków może znaczacy, ale dla refleksji duszpasterskiej, $w$ gruncie rzeczy, mato istotny. Jeśli wpadniemy w pułapke myślenia, że najważniejsze jest podtrzymywanie istniejących spotecznych zjawisk religijności, to nasza troska o Kościót i o duszpasterstwo zostanie w swym rdzeniu sptycona ${ }^{43}$.

Naszkicowana tu „mentalność duszpasterska” stoi u podstaw tzw. „duszpasterstwa akcji”. W nim jednak z trudem odnajduje się coraz więcej wiernych, a zwłaszcza tych, którzy przez T. Halika - w książce uznanej przez „Europejskie Stowarzyszenie Teologii Katolickiej” za najlepszą książkę teologiczną w Europie ostatniego roku - opisani zostali jako „Zacheusze naszych czasów”, których nie zrozumieją ci, którzy najlepiej czują się pośród rozradowanego tłumu ${ }^{44}$, i narzekają wtedy, kiedy widzą puste miejsca w kościele. Owe zaś „,puste miejsca”, zwłaszcza na celebracjach religijnych, odprawianych z racji społecznych, obyczajowych czy politycznych nie oznaczają utraty wiary, odejścia od Kościoła. Zdaniem o. Giertycha prawdziwie wierzacy będa się przy takich przejawach pu-

\footnotetext{
${ }^{42}$ Por. www.efs.gov.pl [z dn. 5.11.2011].

${ }^{43}$ W. G i e r t y c h: Religijność to jeszcze nie wszystko. „Pastores”. R. 2010 nr 4 (49) s. 7.

${ }^{44}$ Por. T. H a 1 i k: Cierpliwość wobec Boga. Spotkanie wiary z niewiara. Tłum. A. B a b u c h o w s ki. Kraków 2011 s. 21.
} 
stej religijności czuli nieswojo, wyczuwając jakąs manipulację rzeczami świętymi dla zupetnie innych celów ${ }^{45}$.

Wracając w zdaniu podsumowującym do refleksji synodalnej, zawartej w Lineamanta, raz jeszcze przytoczę jedno $\mathrm{z}$ istotnych jej stwierdzeń: nadszedt czas, by Kościót wezwat swe wspólnoty chrześcijańskie do nawrócenia duszpasterskiego, ukierunkowania swych działań i struktur na misje”" (Lineamenta 10). Nawrócenie duszpasterskie zawiera w sobie zarówno nawrócenie osobiste, jak i odnowę celów, założeń, struktur, metod i sposobów działania. Samo nawrócenie osobiste nie wystarczy do odnowienia działalności duszpasterskiej ${ }^{46}$.

${ }^{45}$ W. G i e r t y c h: Religijność to jeszcze nie wszystko, dz. cyt., s. 14.

${ }^{46}$ Por. S. L a n z a: Convertire Giona. Pastorale come progetto. Roma 2005 s. 146-148. 